\title{
Corporate social responsibility and earnings management of South African companies
}

\begin{tabular}{|c|c|}
\hline \multicolumn{2}{|c|}{$\begin{array}{l}\text { Authors: } \\
\text { Lauren A. Jordaan }{ }^{1} \text { (]) } \\
\text { Marna de Klerk }{ }^{2} \\
\text { Charl J. de Villiers }\end{array}$} \\
\hline \multicolumn{2}{|c|}{$\begin{array}{l}\text { Affiliations: } \\
{ }^{1} \text { Department of Financial } \\
\text { Accounting, College of } \\
\text { Accounting Sciences, } \\
\text { University of South Africa, } \\
\text { South Africa }\end{array}$} \\
\hline \multicolumn{2}{|c|}{$\begin{array}{l}{ }^{2} \text { Department of Accounting, } \\
\text { University of Pretoria, } \\
\text { South Africa }\end{array}$} \\
\hline \multicolumn{2}{|c|}{$\begin{array}{l}{ }^{3} \text { Graduate School of } \\
\text { Management, Faculty of } \\
\text { Business and Economics, } \\
\text { The University of Auckland, } \\
\text { New Zealand }\end{array}$} \\
\hline \multicolumn{2}{|c|}{$\begin{array}{l}\text { Corresponding author: } \\
\text { Lauren Jordaan, } \\
\text { jordala@unisa.ac.za }\end{array}$} \\
\hline \multicolumn{2}{|c|}{$\begin{array}{l}\text { Received: } 29 \text { Mar. } 2017 \\
\text { Accepted: } 27 \text { Sept. } 2017 \\
\text { Published: } 29 \text { Mar. } 2018\end{array}$} \\
\hline \multicolumn{2}{|c|}{$\begin{array}{l}\text { How to cite this article: } \\
\text { Jordaan, L.A., De Klerk, M. \& } \\
\text { De Villiers, C.J., 2018, } \\
\text { 'Corporate social } \\
\text { responsibility and earnings } \\
\text { management of South } \\
\text { African companies', South } \\
\text { African Journal of Economic } \\
\text { and Management Sciences } \\
21(1) \text {, a1849. https://doi. } \\
\text { org/10.4102/sajems. } \\
\text { v21i1.1849 }\end{array}$} \\
\hline \multicolumn{2}{|c|}{$\begin{array}{l}\text { Copyright: } \\
\text { (c) 2018. The Authors. } \\
\text { Licensee: AOSIS. This work } \\
\text { is licensed under the } \\
\text { Creative Commons } \\
\text { Attribution License. }\end{array}$} \\
\hline \multicolumn{2}{|l|}{ Read online: } \\
\hline 回翼回 & $\begin{array}{l}\text { Scan this QR } \\
\text { code with your } \\
\text { smart phone or } \\
\text { mobile device } \\
\text { to read online. }\end{array}$ \\
\hline
\end{tabular}

Background: Enron was considered a strong corporate social performer when their infamous accounting scandal emerged in 2000. Literature suggests that companies use corporate social responsibility (CSR) to disguise corporate misconduct.

Aim and Setting: This study examines one type of corporate misconduct, namely, earnings management (EM). Prior studies have found significant associations between CSR performance and EM; however, none of these studies controlled for CSR disclosure. This study unbundles the effects of CSR performance and CSR disclosure on EM. To examine the relationship between CSR performance and CSR disclosures and EM of listed South African companies.

Methods: A company included on the Socially Responsible Investment (SRI) ${ }^{1}$ index is used as an indicator of CSR performance. Four measures of CSR disclosure are used.

Results and conclusion: The study tests both CSR performance and CSR disclosure against both real earnings management (REM) and accrual-based earnings management (AEM). CSR performance and earnings management: Companies with better CSR performance were more likely to engage in EM through income increasing discretionary accruals. This suggests that managers who inflate earnings may engage in CSR activities to avoid unwanted scrutiny from stakeholders. Companies with better CSR performance were less likely to engage in REM, suggesting that managers with better CSR performance regard the management of earnings through accruals that reverse in the next period less incriminating than managing earnings through actual company resources. CSR disclosure and earnings management: Companies that integrated their CSR disclosures more into their annual report engaged less in income decreasing discretionary accruals, suggesting that managers with incentives to make more CSR disclosures to reduce information asymmetry will also be less inclined to manage earnings.

\section{Introduction}

Management may engage in corporate social responsibility (CSR) to disguise corporate misconduct (Hemingway \& Maclagan 2004). One form of corporate misconduct, earnings management (EM), is defined as management's use of judgement in financial reporting in order to mislead stakeholders about the underlying financial performance of the company (Healy \& Wahlen 1999).

This study investigated whether companies use CSR to disguise earnings management. Firstly, the study investigated the association between the CSR performance and earnings management of South African companies. The proxy for CSR performance is an indicator of whether the company is included in the Socially Responsible Investment (SRI) index ${ }^{1}$ or not. To be included in the SRI index, companies are independently assessed from public information, only, on whether they meet the environmental performance, social and economic sustainability, corporate governance and commitment to climate change criteria. Assessments are overseen by experts from the investment community, non-governmental organisations (NGOs), unions and academia, which increase their credibility. Companies cannot voluntarily decide to be assessed, and all companies listed on the All Share Index are automatically included.

The study measured earnings management through both discretionary accruals and real earnings management (REM) as managers may manage earnings through either accruals or actual cash flows (Cohen, Dey \& Lys 2008; Zang 2012). Managers use real earnings and accrual-based earnings management (AEM) as substitutes for each other; thus, examining either type in isolation cannot lead to definitive conclusions (Zang 2012).

1.During 2004, the Johannesburg Stock Exchange (JSE) launched the JSE Socially Responsible Investment (SRI) Index (JSE 2014a). Eligibility for inclusion in the SRI index is based primarily on a company's environmental performance, social and economic sustainability, corporate governance and commitment to climate change (JSE 2014b). All companies in the All Share Index are automatically rated against these criteria and a list of companies that meet these criteria is issued annually by the JSE (JSE 2014a, 2014b). 
This study makes some advances on the prior literature. Firstly, it is the first study to ascertain whether companies classified by the Johannesburg Stock Exchange (JSE) as SRIs are, indeed, also 'socially responsible' when it comes to the transparency of their earnings. Secondly, prior studies that tested the relationship between CSR performance and earnings management (Gargouri, Shabou \& Francoeur 2010; Kim, Park \& Wier 2012; Lassaad \& Khamoussi 2012) did not control for the effect of CSR disclosure in their analyses. CSR disclosure has been shown to be significantly correlated with earnings management (Martínez-Ferrero, Garcia-Sachez \& Cuadrado-Ballesteros 2013; Suteja, Gunardi \& Mirawati 2016; Yip, van Staden \& Cahan 2011). By adding an additional variable, namely, CSR disclosure, when testing the relationship between CSR performance and earnings management, this study unbundles the effects of CSR disclosure and CSR performance on earnings management. Thirdly, this study tested the association between CSR disclosure and earnings management of large, listed South African companies, using a rigorous research design. Previous studies have used simple measures of CSR disclosure such as word count, sentence count or page count (Pinto, de Villiers \& Samkin 2014), disregarding the actual content of the disclosure. This study improves on these prior studies by firstly using four different measures of CSR disclosure, including a composite disclosure measure, which analyses the content of the CSR disclosure and not just the amount of disclosure. All data used in the measures of CSR disclosure were independently collected by a reputable audit firm (KPMG Inc.), which increases its credibility. Fourthly, prior studies that tested the association between earnings management and CSR disclosure did not control for CSR performance in their analyses. As discussed, several studies have found significant associations between CSR performance and earnings management; however, none of these studies controlled for this in their analyses.

In terms of practical implications, the results of this study will be useful for investors in their decision-making as they may give insights into the expected transparency of earnings reported by entities classified by the JSE as SRIs. The JSE, and possibly the Financial Times Stock Exchange (FTSE), may also find the results insightful as they might consider adding additional criteria regarding the transparency of earnings when assessing their SRIs. In addition, auditors (both financial and CSR auditors) may consider the findings of this study when determining audit risk, as well as regulators when determining further regulations with respect to CSR disclosures.

The remainder of this paper is set out as follows: the 'Related literature and formulation of hypotheses' section discusses relevant literature and the theoretical framework used in the study and formulates the research hypotheses. 'Method' section describes the research design. 'Results' section presents the results of the study and the 'Conclusion' section contains concluding remarks.

\section{Related literature and formulation of hypotheses Corporate social responsibility performance and earnings management}

It has been suggested that, when acting as agents for shareholders, managers are motivated by self-interest in their decision-making (Healy \& Palepu 2001; Jensen \& Meckling 1976; McWilliams, Siegel \& Wright 2006). Bergstresser and Philippon (2005) find that chief executive officers (CEOs) engage in earnings management for personal gains. On the CSR side, Hemingway and Maclagan (2004) suggest that CSR performance is driven by the personal values of managers. Lawrence et al. (2013) also found that social and environmental practices are driven by the values and beliefs of senior management.

Managers may have an incentive to act ethically or have an incentive to act opportunistically. In line with this theory, prior studies used two main hypotheses to explain the relationship between CSR performance and earnings management: ethical hypothesis and opportunistic hypothesis (Kim et al. 2012).

\section{Ethical hypothesis}

The ethical hypothesis states that managers have an incentive to be ethical, honest and transparent in their financial reporting and to be socially and environmentally responsible in their activities. If stakeholders believed that earnings were being managed or that a company was not being socially responsible, the company concerned may lose value in the market. Turyakira, Venter and Smith (2014) found a positive relationship between society-related CSR activities and competitiveness of small and medium-sized enterprise (SMEs). Martínez-Ferrero, Banerjee and García-Sánchez (2016) found that CSR increases corporate reputation and reduces cost of capital, while earnings management reduces corporate reputation and increases cost of capital. A tarnished corporate reputation, decreased competitiveness and increased cost of capital would have dire consequences for managers (job loss, reduction in salary, etc.). Thus, it is these dire consequences that may motivate managers to act ethically. Such 'ethical' managers would then be less inclined to manipulate earnings, and they would endeavour to ensure that the company's reputation was not compromised by inappropriate social and environmental activities. Kim et al. (2012) found support for this hypothesis in their investigation of a sample of companies in the United States. They found that companies with higher CSR performance scores delivered more transparent financial information to investors. In a study of Malaysian companies, it was found that companies supplying Islamic products (and therefore assumed to be complying with the principle of preserving the interests of society, and not only the interests of the manager) were not engaging in CSR to cover up earnings management (lbrahim et al. 2015). In addition, South Korean firms engaging in CSR (measured as donations expenditure) were also less likely to engage in earnings management through 
discretionary accruals (Pyo \& Lee 2013). Bozzolan et al. (2015), in an international study of 24 countries, found that CSR activities act as a constraint for REM but not AEM. REM negatively affects the future financial performance of a company which CSR-orientated companies seek to avoid. This also suggests some support for the ethical hypothesis as CSR-orientated companies were found to be less likely to engage in REM, which may negatively affect a company's future financial performance. Interestingly, REM seems to be even more constrained by CSR activities in countries with strong legal enforcement (Bozzolan et al. 2015). These results suggest that countrywide institutional factors (e.g. societal values and legal enforcement) may curb a manager's unwanted behaviour and therefore play a moderating role in the relationship between CSR performance and earnings management.

García-Sánchez and García-Meca (2017) also found that socially responsible banks in strict regulatory environments have less earnings management. These results suggest that managers in strong regularity environments have more incentive to be socially responsible in their activities and transparent in their financial reporting than those in weaker regularity environments.

Prior studies have shown that, countrywide, institutional factors influence the relationship between CSR activities (performance) and earnings management. In this study, in order to reduce the 'noise' of institutional factors, we focus solely on South African companies. In doing this, we add to the scant research on the relationship between CSR and earnings management in emerging economies, and to our knowledge, the first to test the relationship in an African country (namely, South Africa).

Accordingly, the first hypothesis may be stated as follows:

H1A: Companies with better CSR performance are less likely to manage earnings.

\section{Opportunistic hypothesis}

It is also possible that managers may have an incentive to act opportunistically in their decisions on whether or not to be socially and environmentally responsible. Prior research has obtained support for the opportunistic hypothesis (Prior, Surroca \& Tribó 2008), with Hemingway and Maclagan (2004) stating that companies may adopt a policy of CSR to cover up corporate misconduct, thereby obtaining the support of stakeholders by diverting their attention.

Grougiou et al. (2014) found that earnings management in US Banks drives CSR, suggesting that bank managers engaging in questionable financial reporting practises are also likely to be engaging in CSR to deflect unwanted attention. MartínezFerrero et al. (2016), in a study of companies in 26 countries, found that as expected CSR had a positive effect on a company's cost of capital. Interestingly, the favourable effect was greater in companies where earnings management was detected. This indicates that stakeholders are unable to identify when CSR is being used to 'greenwash' earning management. Once again, it was found that countrywide institutional factors, specifically the legal environment in which a company operates, play a moderating role with investors less likely to fall for managers' greenwashing antics in common law countries (when compared to civil law countries). This is largely because of increased investor protection in common law countries (Martínez-Ferrero et al. 2016).

While most of the related research has studied developed economies, the research in emerging economies is scant (Muttakin, Khan \& Azim 2015). In one emerging economy, Bangladesh, a civil law country with a poor legal and monitoring environment, it was found that managers use CSR to hide earnings management (Muttakin et al. 2015). Companies in Nigeria, an emerging economy in a poor monitoring environment in Africa, were found to manage earnings less when the board of directors was larger and more independent (Fodio, Ibikunle \& Oba 2013). This suggests that good corporate governance may curb managers from managing earnings when the monitoring environment is weak.

In a recent study of earnings management in South African companies, Pududu and De Villiers (2016) found no evidence of South African managers managing earning to avoid small losses or small decreases in earnings. They, however, mention that this may be because of investors and analysts rather being interested in other reported figures such as headline earnings per share (which may or may not be managed).

Thus, if managers are managing earnings opportunistically and engaging in CSR activities in an attempt to 'greenwash' the misstated financial results, it is feasible to expect a positive relation between CSR performance and earnings management.

The hypothesis may, thus, be stated as a competing hypothesis to H1A:

H1B: Companies with better CSR performance are more likely to manage earnings.

\section{Corporate social responsibility disclosure and earnings management}

Managers may be driven by self-interest (Jensen \& Meckling 1976) in deciding what disclosures to make to shareholders with voluntary CSR disclosures being associated with positive economic outcomes (Healy \& Palepu 2001) such as higher share prices (De Klerk \& De Villiers 2012; De Klerk, De Villiers \& Van Staden 2015; De Villiers \& Marques 2016). CSR disclosures are still primarily voluntary with managers having discretion over what and how much is disclosed (Del Sordo et al. 2016; De Villiers 1998, 1999, 2003; Massa, Farneti \& Scappini 2015; Rao \& Tilt 2016). These decisions are often driven by environmental factors (Amoako, Lord \& Dixon 2017; Borghei, Leung \& Guthrie 2016; Green, Taylor \& Wu 2017; Khan \& Gray 2016; Leung \& Gray 2016; Welbeck 2017). Individual shareholders (De Villiers \& Van Staden 2010a, 
2011) and institutional investors (Solomon \& Solomon 2006) require corporate environmental disclosure, use it in their investment decision-making (Radley Yeldar Limited 2012) and hold companies accountable for their environmental impacts (De Villiers \& Van Staden 2010b). Atkins and Maroun (2015) interviewed institutional investors and found that they thought that reporting on environmental and social issues was an important source of legitimacy in the South African capital markets. Fund managers are also beginning to use these traditional 'soft issues' in their formal analyses (Atkins et al. 2015).

\section{Ethical hypothesis}

Prior studies have found CSR disclosures to be associated with earnings management. Martínez-Ferrero et al. (2013) found a positive relationship between conservative accounting practices and the extent to which managers disclosed their CSR information in line with the Global Reporting Initiative $(\mathrm{GRI})^{2}$ guidelines for CSR reporting. They argue that managers who have incentives to reduce information asymmetry will minimise earnings management and disclose more CSR information to shareholders. In line with this, Chen, Srinidhi, Tsang and Yu (2016) found that companies committed to better financial reporting, proxied by their audit fee expense, are more likely to issue standalone CSR reports. If this is the case, it is feasible to expect a negative relationship between CSR disclosures and earnings management. Thus, the next hypothesis is stated as follows:

H2A: Companies that make more CSR disclosures are less likely to manage earnings.

\section{Opportunistic hypothesis}

Managers with an incentive to manage earnings opportunistically may disclose more CSR information in order to satisfy stakeholders and prevent unwanted scrutiny. Yip et al. (2011) concluded that managers in industries under intense public scrutiny tend to manage earnings less and disclose more CSR information as compared to managers in industries under less public scrutiny. These results suggest that managers who may get away with opportunistic behaviour are more likely to engage in such behaviour. Patten and Trompeter (2003) found that companies with lower levels of CSR disclosures manage earnings downwards during periods of intense political scrutiny, thus also suggesting that managers use CSR disclosures as a tool with which to avoid unwanted scrutiny. Stakeholders may be less likely to scrutinise managers with more CSR disclosures. This will enable managers to hide irregularities (earnings management) behind a curtain of CSR disclosure.

If managers with an incentive to manage earnings disclose more CSR information in order to avoid unwanted scrutiny from stakeholders, it is feasible to expect a positive relation

\footnotetext{
2.The Global Reporting Initiative (GRI) developed a comprehensive, sustainability reporting framework that provides guidelines, metrics and methods for measuring and reporting sustainability-related impacts and performance. The use of these guideline is almost universal, with $78 \%$ of by referring to such guidelines (KPMG 2011). This study used an indicator variable equal to 1 if the company used the GRI guidelines when disclosing CSR information and 0 if not.
}

between CSR disclosures and earnings management. Accordingly, the final hypothesis may be stated as a competing hypothesis to H2A:

H2B: Companies that make more CSR disclosures are more likely to manage earnings.

\section{Method Sample}

The researcher identified all the South African companies for which CSR disclosure data had been collected for the purposes of KPMG's published 2008, 2011 and 2013 reports on CSR reporting practices (KPMG 2008, 2011, 2013). KPMG did not collect CSR disclosure data for the other years. CSR disclosure data for 100 companies for each of the 3 years were collected by KPMG, resulting in an initial sample of 300 company-years. Financial data to compute the earnings management measures for the companies were obtained from the IRESS database. Following prior research, financial companies were eliminated from the final sample because of their differing financial ratios (Zang 2012). The final sample consisted of 214 company-years (72 for 2008, 78 for 2011 and 64 for 2013). Table 1 presents the breakdown of companyyear observations per industry.

\section{Corporate social responsibility performance measure}

During 2004, the JSE launched the JSE SRI Index (JSE 2014a). Eligibility for inclusion in the SRI Index is based primarily on a company's environmental performance, social and economic sustainability, corporate governance and commitment to climate change (JSE 2014b). All companies in the All Share Index are automatically rated against these criteria and a list of companies that meet these criteria is issued annually by the JSE (JSE 2014a, 2014b). The companies cannot voluntarily decide to be rated. Only publicly available information is assessed and no information is accepted directly from the companies. FTSE International Limited (FTSE) calculates the ratings on behalf of the JSE. An independent committee comprising experts from the investment community, NGOs, unions and academia reviews all ratings. This increases the credibility and transparency of the information obtained. The proxy for CSR performance used for the purposes of this study is an indicator variable equal to 1 if the company is included in the SRI Index and 0 if not.

\begin{tabular}{llccc}
\multicolumn{5}{l}{ TABLE 1: } \\
\hline Number & Industry & Frequency & Total (\%) & Cumulative (\%) \\
\hline 1 & Food and beverage & 14 & 6.5 & 6.5 \\
2 & Mining and quarrying & 37 & 17.3 & 23.8 \\
3 & Manufacturing & 71 & 33.2 & 57.0 \\
5 & Construction & 28 & 13.1 & 70.1 \\
6 & Wholesale and retail trade & 48 & 22.4 & 92.5 \\
7 & Transport, storage and & 16 & 7.5 & $\mathbf{1 0 0 . 0}$ \\
\hline Total & communication & & & \\
\hline
\end{tabular}

Note: The industries were classified according to the Standard Industry Classification (SIC) codes used by the Companies Intellectual Property Commission of South Africa (Companies and Intellectual Property Commission of South Africa, n.d.) Financial companies (industry 4) and Intellectual Property Commission of South Africa, n.d.) Financial companies (industry 4)
were eliminated from the sample. The most represented industry is manufacturing (33.2\%), followed by wholesale and retail trade (22.4\%) and mining and quarrying $(17.3 \%)$. 


\section{Corporate social responsibility disclosure measures}

KPMG International analysed the CSR reporting practices of the largest 100 companies, in terms of revenue, in different countries during 2008, 2011 and 2013. Regional KPMG offices collected the data by analysing the CSR disclosures in annual financial reports and stand-alone reports and on company websites, using a questionnaire-based design. The analyses were based on publicly available information only and not on information submitted by companies to KPMG member companies. The data were coded, the questionnaires were compared, and the following four measures of CSR disclosure were developed, used in this study to proxy for CSR disclosure:

- INT ${ }^{3}$ : This measures the level of integration (INT) of the CSR disclosures in the annual report.

- GRI: This indicates whether the company used the GRI guidelines when disclosing CSR information.

- Comp_DIS: This is a composite measure of disclosure combining the level of integration of the CSR disclosures in the annual report (INT) and whether the company issues a stand-alone CSR report and/or CSR information is available on the company's website.

- Comp_ALL: This is a composite, all-inclusive measure which combines the level of integration of the CSR disclosures in the annual report (INT); an indicator if the company uses the GRI guidelines when disclosing CSR information (GRI); an indicator if the company issues a stand-alone CSR report and/or CSR information is available on the company's website; an indicator if a company addresses supply chain issues in its CSR disclosure; an indicator if the CSR disclosures have been assured by a third party; a measure of the scope of any assurance provided on the CSR disclosures (e.g. whether the whole CSR report or only certain chapters and/or indicators were assured); and, finally, a measure of the level of assurance (e.g. positive assurance or limited assurance) provided by the assurance provider.

\section{Earnings management measures}

In line with the suggestions of Kim et al. (2012) and Zang (2012), this study used two measures of earnings management, one that measured discretionary accruals and one that measured REM. The reason for using both measures of earnings management is that managers may manage earnings through accruals and/or actual cash flows (Cohen et al. 2008). Managers use real earnings and AEM as substitutes for each other; thus, examining either type in isolation cannot lead to definitive conclusions (Zang 2012). The more managers manage earnings (through discretionary accruals and/or REM), the less useful the reported financial figures are to stakeholders and the lower the accounting quality of such reported financial figures.

3.If CSR disclosures are made in the directors' report and in a separate section in the annual report, a score of 3 is awarded. If CSR disclosun are made in a separate annual report, a score of 3 is awarded. If CSR disclosures are made in a separate section of the annual report only, a score of 2 is awarded. If CSR disclosures are made in the directors report only, a score of 1 is awarded. If CSR disclosures are no made in the annual report, a score of 0 is awarded. The higher the INT score, the more integrated the CSR disclosure is in the annual report.

\section{Discretionary accruals}

Several prior studies used discretionary accruals as a proxy for earnings management (Cohen \& Zarowin 2010; Kim et al. 2012; Zang 2012). Similarly, this study used discretionary accruals as the first proxy for earnings management as accruals may be used by managers to manage earnings either upwards or downwards. The study used a modified Jones' (1991) model as specified by Dechow, Sloan and Sweeney (1995) and controlled for the book-to-market value of equity (growth) as well as current year cash flows before extraordinary items and discontinued operations (performance) as specified by Larcker, Richardson and Tuna (2007). Using data from the IRESS database, the study estimated discretionary accruals $(\varepsilon)$ for all the companies in the sample per industry for each of the sample-years 2008, 2011 and 2013 (cross-sectional).

In accordance with the literature, this study used the absolute value of discretionary accruals rather than the signed value as all accruals reverse in future periods. In other words, an income decreasing accrual in one period will reverse and increase income in the next period. In an additional analysis, the signed discretionary accruals were split between positive and negative discretionary accruals in order to evaluate whether CSR performance or CSR disclosure (or both) was associated with either positive or negative discretionary accruals (i.e. are these companies using income increasing or income decreasing accruals to manage their earnings?). All accrual estimates were scaled by lagged assets to ensure comparability, as larger firms would naturally have larger accruals than smaller firms.

\section{Real earnings management}

Roychowdhury (2006) defines REM as management actions that are not in line with normal business practices and with the main objective of meeting certain earnings thresholds. Roychowdhury found that companies use REM in order to avoid losses and either to meet or to beat analysts' forecasts. He found that managers increase sales by offering price discounts and lenient credit terms and reduce the cost of inventories sold (COGS) through the overproduction of inventory, which lowers the amount of fixed production costs allocated to each item of inventory (Zang 2012). Roychowdhury (2006) and Zang (2012) also found that managers reduce discretionary expenses such as advertising and research and development expenditure in order to increase profits. Real earnings management is not desirable to stakeholders as it may reduce a company's value in future periods as customers may demand the reduced selling price in the future. Lenient credit sales may increase doubtful debts and increase opportunity costs as debtors need to be financed, while excessive inventory on hand carries additional holding costs, as well as the risks of potential write-downs if the net realisable value falls below the cost price of such inventory. Reducing advertising and research and development costs may reduce future sales, as well as potentially cause companies to lose their competitive advantages. In line with Kim et al.'s (2012) study, this study estimates the abnormal 
cash flows, abnormal production costs (AB_PROD), abnormal discretionary expenses (AB_EXP) as well as a combined measure using the models below.

Abnormal levels of operating cash flows: Lower cash flows than the industry norm in relation to lagged assets ( $\varepsilon$ ) when regressed on sales may indicate earnings management, as cash flows may be lower as a result of managers offering price discounts, etc., to drive sales upwards. In addition, offering more lenient credit terms may also result in sales that are never realised in cash. Thus, lower abnormal cash flows may indicate more REM, through attempts to drive up sales that may not realise in cash, and lower accounting quality.

Abnormal production costs: Higher production costs than the industry norm $(\varepsilon)$ when regressed on sales may indicate earnings management by the overproduction of inventories. The overproduction of inventories reduces the cost of goods sold as the fixed production costs are spread over a larger number of items (assuming that the 'saving' from fixed production costs being allocated to more individual inventory items is greater than the variable costs incurred to produce one additional item). Thus, higher AB_PROD may indicate more REM, through the overproduction of inventory and lower accounting quality.

Abnormal discretionary expenses: If discretionary expenses (e.g. research and development costs) are being reduced in order to meet short-term earnings targets, it is expected that the discretionary expenses regressed on lagged sales will be lower than the industry norm. Thus, lower AB_EXP may indicate more earnings management and lower accounting quality.

Combined real earnings management: The main proxy of REM in this study is calculated by aggregating the three residuals from Models 2.1, 2.2 and 2.3. If managers engage in more REM, it is feasible to expect abnormal levels of operating cash flows (AB_CFO) to be lower, AB_EXP to be lower and AB_PROD to be higher. The AB_PROD were deducted when calculating combined real earnings management (COMBINED_REM) so that positive AB_PROD reduced the COMBINED_REM. Lower COMBINED_REM indicates higher earnings management and lower accounting quality.

\section{Regression models to test hypotheses}

The regression model is based on Kim et al.'s (2012) study. However, it has been extended to include an additional variable of interest, a measure of CSR disclosure in order to 'unbundle' the effects of CSR disclosures and CSR performance on earnings management. CSR performance has been shown to be significantly correlated with earnings management (Gargouri et al. 2010; Kim et al. 2012; Lassaad \& Khamoussi 2012); however, none of these studies controlled for the effect of CSR disclosures.
The main models used in this study to test the association between CSR and earnings management are given below.

Model A:

$\begin{aligned} D A_{i t}(A B S, P O S, N E G) & =\beta_{0}+\beta_{1} \text { CSR_DISCLOSURE }+\beta_{2} S R I_{i t}+ \\ & \beta_{3} \text { COMBINED_REM }_{i t}+\operatorname{SIZE}_{i t-1}+\beta_{5} M B_{i t-1} \\ & +\beta_{6} R O A_{i t-1}+\beta_{7} L E V_{i t-1}+\beta_{8} S H A R E S_{-} \\ & I S S U E D_{i t+1}+\beta_{9} R D_{-} I N T_{i t}+\beta_{10} C O M P A N Y_{-} \\ & A G E_{i t}+\varepsilon\end{aligned}$

$\beta_{1}$ is the first coefficient of interest that tests the association between earnings management through discretionary accruals and CSR disclosure.

$\beta_{2}$ is the second coefficient of interest that tests the association between earnings management through discretionary accruals and CSR performance.

CSR_DISCLOSURE is the measure of CSR disclosure. The measures are detailed in the 'Corporate social responsibility disclosure measures' section of this article.

$S R I$ is the measure of CSR performance and is an indicator of whether the company is listed on the JSE SRI index.

$D A(A B S, P O S, N E G)$ is the measure of earnings management through discretionary accruals computed as the residual of Model 1 in Appendix 1.

COMBINED_REM is the measure of earnings management through REM computed by Model 2.4 in Appendix 1.

SIZE is the natural logarithm of the market value of equity (MVE).

$M B$ proxies for growth calculated as market-to-book equity ratio, measured as MVE divided by book value of equity.

ROA proxies for performance calculated as profit before extraordinary items, scaled by lagged total assets.

$L E V$ is long-term debt scaled by total assets.

SHARES_ISSUED is the number of shares issued in the following year.

$R D \_I N$ is research and development expenditure scaled by total revenue.

COMPANY_AGE is the logarithm of $1+$ number of years since incorporation of the company.

Model B:

$\begin{aligned} \text { COMBINED_REM } & =\beta_{0}+\beta_{1} \text { CSR_DISCLOSURE }+\beta_{2} S R I_{i t} \\ & +\beta_{3} A B S \_D A_{i t}+\beta_{4} S I Z E_{i t-1}+\beta_{5} M B_{i t-1}+ \\ & \beta_{6} R O A_{i t-1}+\beta_{7} L E V_{i t-1}+\beta_{8} S H A R E S \_I S S U E D_{i t+1} \\ & +\beta_{9} R D_{-} I N T_{i t}+\beta_{10} \text { COMPANY_AGE }\end{aligned}$

Open Access 
$\beta_{1}$ is the first coefficient of interest that tests the association between earnings management through REM and CSR disclosure.

$\beta_{2}$ is the second coefficient of interest that tests the association between earnings management through REM and CSR performance.

All other variables are discussed under Model A.

Additional tests, controlling for both year and industry, were conducted. The untabulated results are discussed in the 'Additional regressions controlling for years and industry' section.

\section{Results}

\section{Descriptive statistics}

Table 2 presents the descriptive statistics for the sample. The absolute discretionary accruals (ABS_DA) had a mean of 0.044 of lagged assets, while REM (COMBINED_REM) had a mean of 0.011 of lagged assets. This suggests that, on average, the companies in the sample managed earnings more through discretionary accruals (4.4\% of lagged assets) than through REM (1.1\% of lagged assets). The sample was split between companies with positive discretionary accruals (POS_DA) (101 companies) and those with negative discretionary accruals (NEG_DA) (113 companies). The average POS_DA was $4.9 \%$ of lagged assets, and the average NEG_DA was 3.9\% of lagged assets. Prior research

TABLE 2: Descriptive statistics on selected variables.

\begin{tabular}{lcccc}
\hline Variables & $\boldsymbol{n}$ & Mean & Median & SD \\
\hline Dependent variables & & & & \\
ABS_DA & 214 & 0.044 & 0.030 & 0.049 \\
POS_DA & 101 & 0.049 & 0.036 & 0.054 \\
NEG_DA & 113 & -0.039 & -0.233 & 0.043 \\
AB_CFO & 214 & 0.002 & 0.005 & 0.074 \\
AB_PROD & 214 & -0.009 & 0.028 & 0.317 \\
AB_EXP & 214 & -0.000 & -0.000 & 0.003 \\
COMBINED_REM & 214 & 0.011 & -0.016 & 0.346 \\
Variables of interest & & & & \\
SRI & 214 & 0.519 & 1.000 & 0.501 \\
INT & 214 & 1.54 & 2.00 & 0.96 \\
GRI & 214 & 0.66 & 1.00 & 0.48 \\
Comp_DIS & 214 & 2.08 & 2.00 & 0.98 \\
Comp_ALL & 214 & 4.09 & 4.00 & 2.28 \\
Control variables & & & & \\
SIZE & 214 & 7.160 & 7.078 & 0.685 \\
MB & 214 & 3.133 & 2.038 & 4.880 \\
ROA & 214 & 0.103 & 0.087 & 0.111 \\
LEV & 214 & 0.264 & 0.075 & 2.328 \\
RD_INT & 214 & 0.001 & - & 0.002 \\
COMPANY_AGE & 214 & 1.562 & 1.628 & 0.332 \\
SHARES_ISSUED & 214 & 15330 & 520 & 62506 \\
\hline SER & & & & \\
\hline
\end{tabular}

SRI, CSR performance; INT, GRI, COMP_DIS and COMP_ALL, measures of CSR disclosure; ABS_DA, POS_DA and NEG_DA, measures of earnings management through discretionary accruals; $A B \_C F O, A B \_P R O D, A B \_E X P$ and COMBINED_REM, measures of real earnings management; SIZE, natural logarithm of the MVE; MB, proxy for growth, measured as market management; SIZE, natural logarithm of the MVE; MB, proxy for growth, measured as market
value divided by book value of equity; ROA, proxy for performance, measured as profit before extraordinary items, scaled by lagged total assets. LEV, leverage ratio, measured as long-term debt scaled by total assets; RD_INT, research and development expenditure divided by total debt scaled by total assets; RD_INT, research and development expenditure divided by total
revenue; COMPANY_AGE, natural logarithm of $(1+$ number of years since incorporation of revenue; COMPANY_AGE, natural logarithm of $(1+$ number of years since incorpor
the company); SHARES_ISSUED, number of shares issued in the following year.
(Bergstresser \& Phillippon 2006; Larcker et al. 2007) supports this notion that discretionary accruals, rather than REM, are primarily used for earnings manipulation. Zang (2012) also hypothesises that managers find REM more costly as it represents a departure from optimal operating decisions. Of the sample companies, $51.9 \%$ were listed as SRIs by the JSE. The majority $(66.6 \%)$ of the companies in the sample disclosed CSR information in terms of the GRI guidelines. The median integration level (INT) was 2 out of 3 , which means that the majority of companies in the sample were disclosing CSR information in a separate section of the annual report only. The median composite disclosure score was 2 out of 4 , and the median all-inclusive CSR score was 4 out of 10.

Table 3 depicts the descriptive statistics of the companies that the JSE had classified as SRIs (hereinafter SRI companies) as compared to those companies that had not been classified as such. The average ABS_DA were higher for SRI companies (0.051) than for non-SRI companies (0.036). This difference is statistically significant $(p<0.05)$, suggesting that SRI companies may engage in more earnings management through discretionary accruals than non-SRI companies. The SRI companies had a higher mean of positive discretionary accruals (0.628) as compared to the non-SRI companies (0.325). This may suggest that the SRI companies were managing earnings through income increasing discretionary accruals more than non-SRI companies $(p<0.01)$.

TABLE 3: Descriptive statistics by socially responsible investment versus nonsocially responsible investment companies.

\begin{tabular}{|c|c|c|c|c|c|}
\hline \multirow[t]{2}{*}{ Variable } & \multicolumn{2}{|c|}{ SRI companies } & \multicolumn{2}{|c|}{ Non - SRI companies } & \multirow{2}{*}{$\begin{array}{l}p \text {-value of } \\
\text { difference }\end{array}$} \\
\hline & $n$ & Mean & $n$ & Mean & \\
\hline \multicolumn{6}{|l|}{ Dependent variables } \\
\hline ABS_DA & 111 & 0.0510 & 103 & 0.0360 & $0.025 * *$ \\
\hline POS_DA & 54 & 0.6283 & 47 & 0.3246 & $0.005^{* * *}$ \\
\hline NEG_DA & 57 & -0.0398 & 56 & -0.0390 & 0.918 \\
\hline AB_CFO & 111 & 0.0048 & 103 & -0.0003 & 0.616 \\
\hline$A B \_P R O D$ & 111 & -0.0553 & 103 & 0.0415 & $0.025 * *$ \\
\hline AB_EXP & 111 & 0.0001 & 103 & -0.0002 & 0.501 \\
\hline COMBINED_REM & 111 & 0.0601 & 103 & -0.0420 & $0.031 * *$ \\
\hline \multicolumn{6}{|l|}{ Variables of interest } \\
\hline INT & 111 & 1.5135 & 103 & 1.5631 & 0.706 \\
\hline GRI & 111 & 0.8378 & 103 & 0.4660 & $0.000 * * *$ \\
\hline COMP_DIS & 111 & 2.2072 & 103 & 1.9515 & $0.057^{*}$ \\
\hline COMP_ALL & 111 & 4.8829 & 103 & 3.2330 & $0.000 * * *$ \\
\hline \multicolumn{6}{|l|}{ Control variables } \\
\hline SIZE & 111 & 3.4763 & 103 & 6.8851 & $0.000 * * *$ \\
\hline $\mathrm{MB}$ & 111 & 3.4763 & 103 & 2.7633 & $0.000 * * *$ \\
\hline ROA & 111 & 0.1113 & 103 & 0.0936 & 0.241 \\
\hline LEV & 111 & 0.4315 & 103 & 0.0936 & 0.276 \\
\hline RD_INT & 111 & 0.0012 & 103 & 0.001 & 0.855 \\
\hline COMPANY_AGE & 111 & 1.6185 & 103 & 1.500 & $0.009 * * *$ \\
\hline SHARES_ISSUED & 111 & 20298 & 103 & 9976 & 0.228 \\
\hline
\end{tabular}

ABS_DA, absolute discretionary accruals; POS_DA, positive discretionary accruals; NEG_DA negative discretionary accruals; $A_{B} C F O$, abnormal levels of operating cash flows; $A B$ B $P$ ROOD, abnormal production costs; AB_EXP, abnormal discretionary expenses; COMBINED_REM, combined real earnings management; INT; GRI, Global Reporting Initiative; COMP DIS, composite measure of disclosure; COMP_ALL, composite, all-inclusive measure; SIZE; size of company; MB; market value divided by book value of equity (proxy for growth); ROA; return on assets (proxy for performance);LEV; leverage; RD_INT; research and development intensity; COMPANY AGE, age of company since incorporation; SHARES ISSUED, number of shares issued in the following year.

$*$, indicates significance, two-tailed, at the $10 \%$ level; $* *$, indicates significance, two-tailed, at the $5 \%$ level; $* * *$, indicates significance, two-tailed, at the $1 \%$ level. 
The SRI companies had a higher COMBINED_REM, suggesting less REM than the non-SRI companies $(p<0.05)$. The REM appears to be driven mainly by AB_PROD, with the non-SRI companies managing earnings through the overproduction of inventory more than their SRI counterparts. As expected, SRI companies were more likely to report using the GRI guidelines $(p<0.01)$ and had higher levels of CSR disclosure $(p<0.01)$. The SRI companies were smaller (based on the MVE) with higher growth (based on the market-tobook value of equity). This may show that the smaller companies were trying to gain a competitive advantage over their established competitors, gaining stakeholder support by getting classified as SRIs.

The study tested the control variables for multicollinearity and found that the control variables were not significantly correlated (variance inflation factors (VIF) ranged between 1.026 and 2.017 for both sets of models). Thus, multicollinearity between variables is not a concern in the research design.

\section{Regression results}

\section{Corporate social responsibility performance and earnings management through discretionary accruals}

The results depicted in Table 4 suggest that there is no overall association between earnings management through discretionary accruals (ABS_DA) and CSR performance (SRI). When ABS_DA were split between POS_DA and NEG_ DA, there was a significant positive relation between POS_ DA and SRI $(p<0.05)$, suggesting that companies with better CSR performance are more likely to engage in earnings management through income increasing discretionary accruals. This may suggest that companies that are managing their earnings upwards are engaging in more CSR activities, possibly to divert the attention of investors away from their misconduct. Gargouri et al. (2010) found a positive correlation between CSR performance and earnings management, and suggest that the cost of CSR activities reduce financial performance and subsequently give management an incentive to manage the earnings. This notion finds some support for hypothesis H1B (the opportunistic hypothesis).

TABLE 4: Accrual-based earnings management on corporate social responsibility performance.

\begin{tabular}{llll}
\hline Dependent variables & ABS_DA & POS_DA & NEG_DA \\
\hline $\begin{array}{l}\text { Variable of interest } \\
\text { SRI }\end{array}$ & 0.009 & $0.023^{* *}$ & 0.120 \\
$\begin{array}{l}\text { Control variables } \\
\text { COMBINED_REM }\end{array}$ & 0.002 & 0.005 & \\
SIZE & 0.005 & 0.002 & 0.005 \\
MB & 0.000 & 0.000 & $0.023^{* * *}$ \\
ROA & $0.088^{* * *}$ & $0.274^{* * *}$ & 0.001 \\
LEV & $0.004^{* * *}$ & $0.002^{*}$ & $0.279^{* * *}$ \\
RD_INT & 1.040 & 0.489 & $0.071^{*}$ \\
COMPANY_AGE & 0.005 & 0.007 & 2.446 \\
SHARES_ISSUED & 0.000 & 0.000 & 0.019 \\
\hline
\end{tabular}

SRI, socially responsible investment; COMBINED_REM, combined real earnings management; $M B$, market value divided by book value of equity (proxy for growth); ROA, return on assets (proxy for performance); LEV, leverage; RD_INT, research and development intensity; COMPANY_AGE, age of company since incorporation; SHARES_ISSUED, number of shares issued in the following year.

*, indicates significance, two-tailed, at the $10 \%$ level; $* *$, indicates significance, two-tailed, at the $5 \%$ level; ***, indicates significance, two-tailed, at the $1 \%$ level.
These results hold true, after controlling for the effects of CSR disclosure on earnings management (see 'Corporate social responsibility disclosure and earnings management through discretionary accruals' section). Suteja et al. (2016) found that companies use CSR activities to cover up earnings management and not out of social responsibility and caring. In line with Kim et al.'s (2012) study, the results also suggest that larger companies are less likely to engage in income reducing discretionary accruals as compared to smaller companies $(p<0.01)$. Turning to the control variables, companies with a higher debt ratio leverage (LEV) are more likely to have more positive discretionary accruals and less negative accruals. This is consistent with managers attempting to increase earnings to avoid violating debt agreements (Kim et al. 2012; Yip et al. 2011).

\section{Corporate social responsibility performance and real earnings management}

The results depicted in Table 5 suggest that COMBINED_ REM is positively and significantly $(p<0.05)$ associated with SRI, thereby indicating that companies with better CSR performance are less likely to engage in REM (higher COMBINED_REM indicates lower levels of earnings management). Bozzolan et al. (2015) also found that CSR activities act as a constraint for REM (REM) but not AEM. Real earnings management negatively affects the future financial performance of a company, which CSR-orientated companies seek to avoid. This also suggests some support for the ethical hypothesis as CSR-orientated companies were found to be less likely to engage in REM, which may negatively affect a company's future financial performance. Interestingly, REM seems to be even more constrained by CSR activities in countries with strong legal enforcement (Bozzolan et al. 2015).

In the untabulated results, consistent with our descriptive statistics, the measure of COMBINED_REM is primarily driven by the overproduction of inventory (AB_PROD) in order to reduce the fixed cost allocated per item and, ultimately, to reduce the cost of sales. Thus, companies with better CSR performance are less likely to engage in REM,

TABLE 5: Real earnings management on corporate social responsibility performance.

\begin{tabular}{ll}
\hline Dependent variable & COMBINED_REM \\
\hline $\begin{array}{l}\text { Variable of interest } \\
\text { SRI }\end{array}$ & $0.119^{*}$ \\
Control variables & \\
ABS_DA & 0.098 \\
SIZE & -0.054 \\
MB & 0.007 \\
ROA & $0.555^{*}$ \\
LEV & -0.004 \\
RD_INT & $20.930 *$ \\
COMPANY_AGE & -0.040 \\
SHARES_ISSUED & -0.000 \\
\hline
\end{tabular}

COMBINED REM, combined real earnings management; SRI, socially responsible investment; ABS_DA, absolute discretionary accruals; SIZE, size of company; MB, market value divided by book value of equity (proxy for growth) ; ROA, return on assets (proxy for performance); LEV, leverage; RD__NT, research and development intensity; COMPANY_AGE, age of company since incorporation; SHARES ISSUED, number of shares issued in the

*, indicates significance, two-tailed, at the $5 \%$ level. 
specifically relating to the overproduction of inventory. This notion finds some support for hypothesis H1A (the ethical hypothesis). These results hold true after controlling for the effects of CSR disclosure on earnings management (see 'Corporate social responsibility disclosure and real earnings management' section). Managers use REM and AEM as substitutes for one another, based on their relative costliness (Bozzolan et al. 2015; Zang 2012). Real earnings management potentially imposes a greater future cost on the company than AEM (Roychowdhury 2006) and is less likely to be detected (Zang 2012), which may explain why these 'ethical' managers find it less incriminating to increase profits through discretionary accruals (that will reverse in future periods) than to engage in REM with actual company resources. Kim et al. (2012) found that CSR activities were associated with less REM, finding support for the ethical hypothesis. Turning to the control variables, companies with better financial performance (ROA) (Kim et al. 2012), as well as those that employ more financial resources in research and development, are less likely to engage in REM.

\section{Corporate social responsibility disclosure and earnings management through discretionary accruals}

The results depicted in Table 6 suggest that there is no overall association between earnings management through discretionary accruals (ABS_DA) and CSR disclosure (COMP_ALL). However, when splitting the discretionary accruals between POS_DA and NEG_DA there was a significant positive relationship between NEG_DA and INT $(p<0.05)$, suggesting companies that integrate their CSR disclosures in their annual report engage in less earnings management through income reducing discretionary accruals. Thus, in line with the above, some support is found for hypothesis H2A (the ethical hypothesis). Prior research testing the association between CSR disclosure and earnings management has found support for the ethical hypothesis (Chen et al. 2016; Martínez-Ferrero et al. 2013). Chen et al.
(2016) argue that managers with a high degree of integrity and commitment towards financial stakeholders are most likely going to exert the same effort to all stakeholders, hence the issuance of a stand-alone CSR report.

After controlling for the effects of CSR disclosure, companies listed as SRI were still more likely to engage in income increasing discretionary accruals (POS_DA) as compared to those not listed as such $(p<0.05)$.

Turning to the control variables, once again, indebted companies with higher LEV were found to manage earnings upwards (positive POS_DA) and positive (less negative) NEG_DA, and bigger companies were found to be managing earnings downwards.

\section{Corporate social responsibility disclosure and real earnings management}

The results depicted in Table 7 suggest that there is no overall association between REM and CSR disclosure. Once again, after controlling for the effects of CSR disclosure, the results revealed that COMBINED_REM is positively and significantly $(p<0.05)$ associated with SRI, again suggesting that companies with better CSR performance are less likely to engage in REM (higher COMBINED_REM indicates lower levels of earnings management).

\section{Additional regressions controlling for years and industry}

\section{Corporate social responsibility performance and earnings management}

Yip et al. (2011) found that industry is an important driver of the relationships between earnings management and CSR disclosures. Once again, the untabulated results showed no significant association between ABS_DA and SRI, suggesting that there is no overall association between earnings management through discretionary accruals and CSR

TABLE 6: Accrual-based earnings management on corporate social responsibility disclosure.

\begin{tabular}{|c|c|c|c|c|c|c|c|c|c|c|c|c|}
\hline \multirow[t]{2}{*}{ Dependent variables } & \multicolumn{4}{|c|}{ ABS_DA } & \multicolumn{4}{|c|}{ POS_DA } & \multicolumn{4}{|c|}{ NEG_DA } \\
\hline & INT & GRI & COMP_DIS & COMP_ALL & INT & GRI & COMP_DIS & COMP_ALL & INT & GRI & COMP_DIS & COMP_ALL \\
\hline \multicolumn{13}{|l|}{ Variables of interest } \\
\hline INT & -0.002 & - & - & - & 0.007 & - & - & - & $0.010 * *$ & - & - & - \\
\hline GRI & - & 0.011 & - & - & - & 0.004 & - & - & - & 0.005 & - & - \\
\hline COMP_DIS & - & - & -0.004 & - & - & - & 0.002 & - & - & - & $0.010 * * *$ & - \\
\hline COMP_ALL & - & - & - & 0.001 & - & - & - & 0.003 & - & - & - & 0.001 \\
\hline SRI & 0.009 & 0.006 & 0.009 & 0.007 & $0.023 * *$ & $0.022 * *$ & $0.023 * *$ & $0.020 * *$ & 0.013 & 0.011 & 0.010 & 0.011 \\
\hline COMBINED_REM & 0.002 & 0.001 & 0.002 & 0.002 & -0.006 & -0.005 & -0.005 & -0.006 & 0.006 & 0.004 & 0.006 & 0.005 \\
\hline SIZE & 0.005 & 0.003 & 0.007 & 0.003 & 0.005 & -0.003 & -0.003 & -0.008 & $0.022 * * *$ & $0.024 * * *$ & $-0.025 * * *$ & $0.025 * * *$ \\
\hline $\mathrm{MB}$ & -0.000 & -0.000 & -0.000 & -0.000 & 0.001 & -0.001 & -0.001 & -0.001 & -0.001 & 0.000 & -0.001 & -0.001 \\
\hline ROA & $0.084 * *$ & $0.094 * * *$ & $0.078 * *$ & $0.099 * * *$ & $0.295 * * *$ & $0.274 * * *$ & $0.280 * * *$ & $0.295 * * *$ & $0.298 * * *$ & $0.286 * * *$ & $0.314 * * *$ & $0.292 * * *$ \\
\hline LEV & $0.004 * * *$ & $0.004 * * *$ & $0.004 * * *$ & $0.004^{* *}$ & $0.002 *$ & $0.002 *$ & $0.002^{*}$ & $0.002 *$ & $0.074 *$ & $0.072 *$ & $0.075 * *$ & $0.071 *$ \\
\hline RD_INT & 1.015 & 1.000 & 1.148 & 1.012 & -0.445 & -0.421 & -0.561 & -0.587 & -2.141 & -2.548 & -2.550 & -2.418 \\
\hline SHARES_ISSUED & -0.000 & -0.000 & -0.000 & -0.000 & -0.000 & -0.000 & -0.000 & -0.000 & -0.000 & -0.000 & -0.000 & -0.000 \\
\hline
\end{tabular}

NEG_DA, negative discretionary accruals; INT; GRI, Global Reporting Initiative; COMP_DIS, composite measure of disclosure; COMP_ALL, composite, all-inclusive measure; SRI, socially responsible investment; COMBINED_REM, combined real earnings management; SIZE, size of company; MB, market value divided by book value of equity (proxy for growth) ; ROA, return on assets (proxy for performance); LEV, leverage; RD_INT, research and development intensity; COMPANY_AGE, age of company since incorporation; SHARES_ISSUED, number of shares issued in the following year.

$*$, indicates significance, two-tailed, at the $10 \%$ level; **, indicates significance, two-tailed, at the $5 \%$ level; ***, indicates significance, two-tailed, at the $1 \%$ level.

Note: Higher NEG_DA indicates lower levels of earnings management through income reducing discretionary accruals. Table 6 shows the results of equation: $D A_{i t}(A B S, P O S, N E G)=\beta_{0}+\beta_{1}$

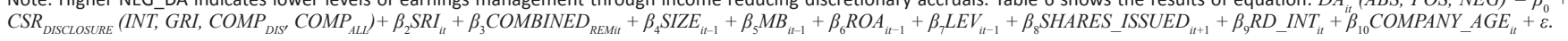


TABLE 7: Real earnings management on corporate social responsibility disclosure.

\begin{tabular}{lcccc}
\hline $\begin{array}{l}\text { Dependent } \\
\text { variable }\end{array}$ & \multicolumn{4}{c}{ COMBINED_REM } \\
\cline { 2 - 5 } Variables of interest & INT & GRI & COMP_DIS & COMP_ALL \\
\cline { 2 - 5 } INT & -0.005 & - & - & - \\
GRI & - & 0.051 & - & - \\
COMP_DIS & - & - & -0.004 & - \\
COMP_ALL & - & - & - & 0.004 \\
Control variables & & & & \\
SRI & $0.119 * *$ & $0.105^{*}$ & $0.120^{* *}$ & $0.116^{* *}$ \\
ABS_DA & 0.194 & 0.055 & 0.092 & 0.090 \\
SIZE & -0.053 & -0.064 & -0.052 & -0.060 \\
MB & 0.007 & 0.007 & 0.007 & 0.007 \\
ROA & $0.546 *$ & $0.581^{* *}$ & $0.545^{* *}$ & $0.581^{* *}$ \\
LEV & -0.004 & -0.003 & -0.004 & -0.004 \\
RD_INT & $20.873 * *$ & $20.701 * *$ & $21.032^{* *}$ & $20.856^{* *}$ \\
COMPANY_AGE & -0.040 & -0.042 & -0.040 & -0.041 \\
SHARES_ISSUED & -0.000 & -0.000 & -0.000 & -0.000 \\
\hline
\end{tabular}

Note: This table shows the results of equation: COMBINED REM $=\beta_{0}+\beta_{1} S R I_{1}+\beta_{2} A B S$ $D A_{i t}+\beta_{3} S I Z E_{i t-1}+\beta_{4} M B_{i t-1}+\beta_{5} R O A_{i t-1}+\beta_{6} L E V_{i t-1}+\beta_{7} S H A \bar{R} E S$ ISSUED ${ }_{i t+1}+\beta_{8} R D_{-} I N T_{i t}+$ $\beta_{9}{ }_{9}^{i t}$ OMPANY $A G E_{i t}+\varepsilon$. Higher COMBINED_REM indicates lower levels of real earnings management (refer to 'Earnings management measures' section for more detail).

COMBINED_REM, Combined real earnings management; INT; GRI, Global Reporting Initiative; COMP DIS, composite measure of disclosure; COMP ALL, composite, all-inclusive measure; SRI, socially responsible investment; ABS DA, absolute discretionary accruals; SIZE, size of company; $M B$, market value divided by size of company; MB, market value divided by book value of equity (proxy for growth); ROA return on assets (proxy for performance); LEV, leverage; RD_INT, research and development intensity; COMPANY_AGE, age of company since incorporation; SHARES_ISSUED, number of
shares issued in the following year.

*, indicates significance, two-tailed, at the $10 \%$ level; **, indicates significance, two-tailed, at the $5 \%$ level; ***, indicates significance, two-tailed, at the $1 \%$ level.

performance. However, the study found a positive significant relationship $(p<0.05)$ between CSR performance and earnings management through positive discretionary accruals after controlling for year and industry effects on earnings management. In addition, the study found that companies with better CSR performance are less likely to manage earnings downwards through discretionary accruals (NEG_DA) $(p<0.05)$. Once again, the study found that COMBINED_REM is positively and significantly $(p<0.05)$ associated with SRI, indicating that companies with better CSR performance are less likely to engage in REM. On the other hand, the study did not find any significant differences in COMBINED_REM between any of the industries or years.

\section{Conclusion}

This study tested the relationship between both CSR performance and CSR disclosure and earnings management of listed South African companies. The study unbundled the effects of CSR disclosure and CSR performance on earnings management using a rigorous research design.

\section{Corporate social responsibility performance and earnings management}

The JSE annually assesses listed companies' CSR performance and issues a SRI index. A company included on this index is seen to be a better CSR performer and, as such, is used in this study as an indicator of CSR performance.

The overall results found no association between CSR performance and either AEM or REM when controlling for CSR disclosure. However, it was found that companies with better CSR performance are more likely to engage in earnings management through income increasing discretionary accruals. Prior studies have suggested that managers act in self-interest and inflating earnings may result in better job security, earnings potential, etc., for managers. The results suggest that managers who are inflating earnings may engage in CSR activities in an attempt to 'greenwash' their misstated earnings to avoid unwanted scrutiny from stakeholders.

Prior studies have shown that countrywide institutional factors influence the relationship between CSR activities (performance) and earnings management. In this study, in order to reduce the 'noise' of institutional factors, we focused solely on South African companies. In doing this, we add to the scant research on the relationship between CSR and earnings management in emerging economies, and to our knowledge, the first to test the relationship in an African country (namely, South Africa).

It was also found that South African companies with better CSR performance are less likely to engage in REM. This may suggest that managers with better CSR performance regard the management of earnings through accruals that reverse in the next period to be less incriminating than managing earnings through actual company resources.

\section{Corporate social responsibility disclosure and earnings management}

The study also evaluated the relationship between the earnings management and four measures of CSR disclosure of large South African companies, while controlling for CSR performance. The overall results found no association between CSR disclosure and either AEM or REM. However, it was found that companies that integrated their CSR disclosures more into their annual report engaged less in income decreasing discretionary accruals. Prior studies have suggested that managers act in self-interest and, if stakeholders believed that earnings were being managed or that a company was being socially or environmentally unethical, it may result in salary cuts or job losses for managers. The results may suggest that managers with incentives to make more CSR disclosures to reduce information asymmetry avoid unwanted attention from lobby groups and tax authorities or gain stakeholder support, will also be less inclined to manage earnings.

This study makes some advances on the prior literature. Firstly, it is the first study to ascertain whether companies classified by the JSE as SRIs are, indeed, also 'socially responsible' when it comes to the transparency of their earnings. Secondly, prior studies that tested the relationship between CSR performance and earnings management did not control for the effect of CSR disclosure in their analyses. CSR disclosure has been shown to be significantly correlated with earnings management. By adding an additional variable, namely CSR disclosure, when testing the relationship between CSR performance and earnings management, this 
study unbundles the effect of CSR disclosure and CSR performance on earnings management.

Thirdly, this study tested the association between CSR disclosure and earnings management of large, listed South African companies by using a rigorous research design. Previous studies have used simple measures of CSR disclosure such as word count, sentence count or page count, disregarding the actual content of the disclosure. This study improves on these prior studies by firstly using four different measures of CSR disclosure, including a composite disclosure measure that analyses the content of the CSR disclosure and not just the amount of disclosure. All data used in the measures of CSR disclosure were independently collected by a reputable audit firm (KPMG), which increases its credibility. In addition, prior studies which tested the association between earnings management and CSR disclosure did not control for CSR performance in their analyses.

In terms of practical implications, the results of this study will be useful for investors in their decision-making as it may give insights into the expected transparency of earnings reported by entities classified as SRIs. The JSE may also find the results insightful, as they might consider adding additional criteria regarding the management of earnings when assessing their SRIs.

Future research may test the association between CSR and earnings management over a broader time frame, using a larger sample that incorporates smaller as well as unlisted companies in order to increase the generalisability of the conclusions reached.

\section{Acknowledgements Competing interests}

The authors declare that they have no financial or personal relationship(s) that may have inappropriately influenced them in writing this article.

\section{Authors's contributions}

L.A.J. (University of South Africa) was responsible for generating the idea, gathering the data, performing the analyses, concluding and writing the article. M.D.K. (University of Pretoria) and C.J.D.V. (University of Auckland, New Zealand and University of Pretoria) were involved in providing guidance throughout the process.

\section{References}

Amoako, K.O., Lord, B.R. \& Dixon, K., 2017, 'Sustainability reporting: Insights from the websites of five plants operated by Newmont Mining Corporation', Meditari Accountancy Research 25(2), 186-215.

Atkins, J. \& Maroun, W., 2015, 'Integrated reporting in South Africa in 2012 Perspectives from South African institutional investors', Meditari Accountancy Research 23(2), 197-221. https://doi.org/10.1108/MEDAR-07-2014-0047

Atkins, J.F., Solomon, A., Norton, S. \& Joseph, N.L., 2015, 'The emergence of integrated private reporting', Meditari Accountancy Research 23(1), 28-61. https://doi. org/10.1108/MEDAR-01-2014-0002

Bergstresser, D. \& Philippon, T., 2006, 'CEO incentives and earnings management', Journal of Financial Economics 80(2006), 511-529. https://doi.org/10.1016/j. jineco.2004.10.011
Borghei, Z., Leung, P. \& Guthrie, J., 2016, 'The nature of voluntary greenhouse gas disclosure - An explanation of the changing rationale: Australian evidence', Meditari Accountancy Research 24(1), 111-133. https://doi.org/10.1108/MEDARMed-2015-0008

Bozzolan, S., Fabrizi, M., Mallin, C.A. \& Michelon, G., 2015, 'Corporate social responsibility and earnings quality: International evidence', The Internationa Journal of Accounting 50(4), 361-396. https://doi.org/10.1016/j.intacc.2015. 10.003

Chen, L., Srinidhi, B., Tsang, A. \& Yu, W., 2016, 'Audited financial reporting and voluntary disclosure of Corporate Social Responsibility (CSR) Reports', Journal of Management Accounting Research 28(2), 53-76. https://doi.org/10.2308/jmar51411

Cohen, D.A., Dey, A. \& Lys, T.Z., 2008, 'Real and accrual-based earnings management in the pre-and post-Sarbanes-Oxley periods', The Accounting Review 83(3), in the pre-and post-Sarbanes-Oxley periods', The
757-787. https://doi.org/10.2308/accr.2008.83.3.757

Cohen, D.A. \& Zarowin, P., 2010, 'Accrual-based and real earnings management activities around seasoned equity offerings', Journal of Accounting and Economics 50(1), 2-19. https://doi.org/10.1016/j.jacceco.2010.01.002

Companies and Intellectual Property Commission, n.d., Standard Industria Classification Codes (SIC), viewed 31 August 2014, from http://www.cipro.gov.za/ info_library/sic_codes.asp

Dechow, P.M., Sloan, R.G. \& Sweeney, A.P., 1995, 'Detecting earnings management', Accounting Review 70(2), 193-225.

De Klerk, M. \& De Villiers, C., 2012, 'The value relevance of corporate responsibility reporting: South African evidence', Meditari Accountancy Research 20(1), 21-38. https://doi.org/10.1108/10222521211234200

De Klerk, M., De Villiers, C. \& Van Staden, C., 2015, 'The influence of corporate social responsibility disclosure on share prices: Evidence from the United Kingdom', Pacific Accounting Review 27(1), 208-228. https://doi.org/10.1108/PAR-05-20130047

De Villiers, C., 1998, 'The willingness of South Africans to support more green reporting', South African Journal of Economic and Management Sciences 1(1), 145-167.

De Villiers, C., 2003, 'Why do South African companies not report more environmental information when managers are so positive about this kind of reporting?', Meditari Accountancy Research 11(1), 11-23. https://doi.org/10.1108/102225 29200300002

De Villiers, C. \& Marques, A., 2016, 'Corporate social responsibility, country-level predispositions, and the consequences of choosing a level of disclosure' Accounting and Business Research 46(2), 167-195. https://doi.org/10.1080/0001 4788.2015 .1039476

De Villiers, C. \& Van Staden, C.J., 2010a, 'Shareholders' requirements for corporate environmental disclosures: A cross country comparison', British Accounting Review 42(4), 227-240. https://doi.org/10.1016/j.bar.2010.08.002

De Villiers, C. \& Van Staden, C.J., 2010b, 'Why do shareholders require corporate environmental disclosure?', South African Journal of Economic and Management Sciences 13(4), 437-446. https://doi.org/10.4102/sajems.v13i4.99

De Villiers, C. \& Van Staden, C.J., 2011, 'Shareholder requirements for compulsory environmental information in annual reports and on websites', Australian Accounting Review 21(4), 317-326. https://doi.org/10.1111/j.1835-2561.2011. 00144.x

De Villiers, C.J., 1999, 'The decision by management to disclose environmental information: A research note based on interviews', Meditari Accountancy Research 7, 33-48.

Del Sordo, C., Farneti, F., Guthrie, J., Pazzi, S. \& Siboni, B., 2016, 'Social reports in Italian universities: Disclosures and preparers' perspective', Meditari Accountancy Research 24(1), 91-110. https://doi.org/10.1108/MEDAR-09-2014-0054

Fodio, M.I., Ibikunle, J. \& Oba, V.C., 2013, 'Corporate governance mechanisms and reported earnings quality in listed Nigerian insurance firms', International Journal of Finance and Accounting 2(5), 279-286.

García-Sánchez, I.M. \& García-Meca, E., 2017, 'CSR engagement and earnings quality in banks. The moderating role of institutional factors', Corporate Social Responsibility and Environmental Management 24(2), 145-158. https://doi. org/10.1002/csr.1405

Gargouri, R.M., Shabou, R. \& Francoeur, C., 2010, 'The relationship between corporate social performance and earnings management', Canadian Journal of Administrative Sciences 27(4), 320-334. https://doi.org/10.1002/cjas.178

Green, W., Taylor, S. \& Wu, J., 2017, 'Determinants of greenhouse gas assurance provider choice', Meditari Accountancy Research 25(1), 114-135. https://doi. org/10.1108/MEDAR-08-2016-0072

Grougiou, V., Leventis, S., Dedoulis, E. \& Owusu-Ansah, S., 2014, 'Corporate social responsibility and earnings management in US banks', Accounting Forum 38(3), 155-169. https://doi.org/10.1016/j.accfor.2014.05.003

Healy, P.M. \& Palepu, K.G., 2001, 'Information asymmetry, corporate disclosure, and the capital markets: A review of the empirical disclosure literature', Journal of Accounting and Economics 31(1), 405-440. https://doi.org/10.1016/S01654101(01)00018-0

Healy, P.M. \& Wahlen, J.M., 1999, 'A review of the earnings management literature and its implications for standard setting', Accounting Horizons 13(4), 365-383. https://doi.org/10.2308/acch.1999.13.4.365

Hemingway, C.A. \& Maclagan, P.W., 2004, 'Managers' personal values as drivers of corporate social responsibility', Journal of Business Ethics 50(1), 33-44. https:// doi.org/10.1023/B:BUSI.0000020964.80208.c9 
Ibrahim, M.S., Darus, F., Yusoff, H. \& Muhamad, R., 2015, 'Analysis of earnings management practices and sustainability reporting for corporations that offer

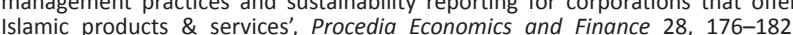
Islamic products \& services', Procedia Econom
https://doi.org/10.1016/S2212-5671(15)01098-9

Jensen, M.C. \& Meckling, W.H., 1976, 'Theory of the firm: Managerial behavior, agency costs, and ownership structure', Journal of Financial Economics 3(4), 305360. https://doi.org/10.1016/0304-405X(76)90026-X

Johannesburg Stock Exchange (JSE), 2014a, SRI Index: Background and criteria 2014, JSE Limited, viewed 01 September 2014, from https://www.jse.co.za/content/ JSERulesPoliciesandRegulationltems/Background\%20and\%20Criteria\%202014.pdf

Johannesburg Stock Exchange (JSE), 2014b, Ground rules for the management of the SRI Indices April 2014, JSE Limited, viewed 01 September 2014, from https:// www.jse.co.za/content/JSERulesPoliciesandRegulationItems/Ground $\% 20$ Rules\%202014.pdf

Jones, J., 1991, 'Earnings management during import relief investigations', Journal of Accounting Research 29(2), 193-228. https://doi.org/10.2307/2491047

Khan, T. \& Gray, R., 2016, 'Accounting, identity, autopoiesis+ sustainability: A comment, development and expansion on Lawrence, Botes, Collins \& Rope (2013)', Meditari Accountancy Research 24(1), 36-55. https://doi.org/10.1108/ MEDAR-06-2015-0032

Kim, Y., Park, M.S. \& Wier, B., 2012, 'Is earnings quality associated with corporate social responsibility?' The Accounting Review 87(3), 761-796. https://doi. org/10.2308/accr-10209

KPMG International Survey of Corporate Responsibility Reporting, 2008, viewed 31 August 2014, from http://www.kpmg.com/cn/en/issuesandinsights/ August 2014, from http://www.kpmg.com/cn/en/issuesandin
articlespublications/pages/corporateresponsibility-survey-200810-o.aspx

KPMG International Survey of Corporate Responsibility Reporting, 2011, viewed 31 August 2014, from http://www.kpmg.com/PT/pt/IssuesAndlnsights/Documents/ corporate-responsibility2011.pd

KPMG International Survey of Corporate Responsibility Reporting, 2013, viewed 31 August 2014, from http://www.kpmg.com/Global/en/IssuesAndInsights/ ArticlesPublications/corporateresponsibility/Pages/corporate-responsibilityreporting-survey-2013.aspx

Larcker, D.F., Richardson, S.A. \& Tuna, I., 2007, 'Corporate governance, accounting outcomes, and organizational performance', The Accounting Review 82(4), 9631008. https://doi.org/10.2308/accr.2007.82.4.963

Lassaad, B.M. \& Khamoussi, H., 2012, 'Determinants of communication about corporate social responsibility: Case of French companies', International journal of Contemporary Business Studies 3(5), 49-60.

Lawrence, S.R., Botes, V., Collins, E. \& Roper, J., 2013, 'Does accounting construct the identity of firms as purely self-interested or as socially responsible?', Meditari Accountancy Research 21(2), 144-160. https://doi.org/10.1108/MEDAR-09-2012-0030

Leung, T.C.H. \& Gray, R., 2016, 'Social responsibility disclosure in the internationa gambling industry: A research note', Meditari Accountancy Research 24(1), 73-90. gambling industry: A research note', Meditari Accou
https://doi.org/10.1108/MEDAR-01-2015-0001

Martínez-Ferrero, J., Banerjee, S. \& García-Sánchez, I.M., 2016, 'Corporate socia responsibility as a strategic shield against costs of earnings management practices', Journal of Business Ethics 133(2), 305-324. https://doi.org/10.1007/ s10551-014-2399-x

Martínez-Ferrero, J., García-Sánchez, I. \& Cuadrado-Ballesteros, B., 2013, 'Effect of financial reporting quality on sustainability information disclosure', Corporate Social Responsibility and Environmental Management 22(1), 45-64. https://doi. org $/ 10.1002 /$ csr.1330

Massa, L., Farneti, F. \& Scappini, B., 2015, 'Developing a sustainability report in a small to medium enterprise: Process and consequences', Meditari Accountancy Research 23(1),62-91. https://doi.org/10.1108/MEDAR-02-2014-0030
Mcwilliams, A., Siegel, D.S. \& Wright, P.M., 2006, 'Corporate social responsibility: Strategic implications', Journal of Management Studies 43(1), 1-18. https://doi. org/10.1111/j.1467-6486.2006.00580.x

Muttakin, M.B., Khan, A. \& Azim, M.I., 2015, 'Corporate social responsibility disclosures and earnings quality: Are they a reflection of managers' opportunistic behavior?', Managerial Auditing Journal 30(3), 277-298. https://doi.org/10.1108/ MAJ-02-2014-0997

Patten, D. \& Trompeter, G., 2003, 'Corporate responses to political costs: An examination of the relation between environmental disclosure and earnings management', Journal of Accounting and Public Policy 22(1), 83-94. https://doi. org/10.1016/S0278-4254(02)00087-X

Pinto, S., De Villiers, C. \& Samkin, G., 2014, 'Corporate social responsibility disclosures during the global financial crisis: New Zealand evidence', New Zealand Journal of Applied Business Research 12(2), 33-49.

Prior, D., Surroca J. \& Tribó J.A., 2008, 'Are socially responsible managers really ethical? Exploring the relationship between earnings management and corporate socia responsibility', Corporate Governance: An International Review 16(3), 160-177. https://doi.org/10.1111/j.1467-8683.2008.00678.x

Pududu, M.L. \& De Villiers, C., 2016, 'Earnings management through loss avoidance: Does South Africa have a good story to tell?', South African Journal of Economic and Management Sciences 19(1), 18-34. https://doi.org/10.17159/2222 $3436 / 2016 / v 19 n 1 a 2$

Pyo, G. \& Lee, H.Y., 2013, 'The association between corporate social responsibility activities and earnings quality: Evidence from donations and voluntary issuance of CSR reports', Journal of Applied Business Research (JABR) 29(3), 945-962. https:// doi.org/10.19030/jabr.v29i3.7793

Radley Yeldar Limited, 2012, The value of extra financial disclosure: What investors and analysts said, London, viewed 01 September 2014, from https:// www.globalreporting.org/resourcelibrary/The-value-of-extra-financialdisclosure.pdf

Rao, K. \& Tilt, C., 2016, 'Board diversity and CSR reporting: An Australian study', Meditari Accountancy Research 24(2), 182-210. https://doi.org/10.1108/ MEDAR-08-2015-0052

Roychowdhury, S., 2006, 'Earnings management through real activities manipulation', Journal of Accounting and Economics 42(3), 335-370. https://doi.org/10.1016/j. jacceco.2006.01.002

Solomon, J.F. \& Solomon, A., 2006, 'Private, social, ethical and environmental disclosure', Accounting, Auditing \& Accountability Journal 19(4), 564-591. https:// doi.org/10.1108/09513570610679137

Suteja, J., Gunardi, A. \& Mirawati, A., 2016, 'Moderating effect of earnings management on the relationship between corporate social responsibility disclosure and profitability of banks in Indonesia', International Journal of Economics and Financial Issues 6(4), 1360-1365.

Turyakira, P., Venter, E. \& Smith, E., 2014, 'The impact of corporate social responsibility on the competitiveness of small and medium-sized entities', South African Journal of Economic and Management Sciences 17(2), 157-172. https://doi.org/10.4102/ of Economic and
sajems.v17i2.443

Welbeck, E.E., 2017, 'The influence of institutional environment on corporate responsibility disclosures in Ghana', Meditari Accountancy Research 25(2), 216-240.

Yip, E., Van Staden, C. \& Cahan, S., 2011, 'Corporate social responsibility reporting and earnings management: The role of political costs', Australasian Accounting Business \& Finance Journal 5(3), 17-34.

Zang, A., 2012, 'Evidence on the trade-off between real activities manipulation and accrual-based earnings management', The Accounting Review 87(2), 675-703. https://doi.org/10.2308/accr-10196 


\section{Appendix 1}

\section{Model 1: Discretionary accruals (ABS_DA, POS_DA, NEG_DA)}

$T A_{i t}=\alpha+\beta_{1}\left(\Delta \operatorname{Rev}_{i t}-\Delta \operatorname{Rec}_{i t}\right)+\beta_{2} P P E_{i t}+\beta_{3} B M_{i t}+\beta_{4} C F O_{i t}+\square_{i t}$

- $\quad$ ABS_DA is the absolute value of discretionary accruals

- POS_DA is positive (income increasing) discretionary accruals

- NEG_DA is negative (income decreasing) discretionary accruals

where discretionary accruals is computed as the residual([).

- $T A$ is profitless cash flows from operations.

- $\Delta \operatorname{Rev}$ is the change in revenue from prior to current year.

- $\triangle R e c$ is the change in trade receivables from prior to current year.

- $P P E$ is the book value of property, plant and equipment at year end.

- $B M$ is the book-to-market value of ordinary shares at year end.

- $\quad C F O$ is cash flows from operations.

\section{Model 2: Real earnings management} Abnormal levels of operating cash flows (AB_CFO)

$C F O_{i t} / A_{i,-1}=\alpha+\beta_{1}\left(1 / A_{i, t-1}\right)+\beta_{2}\left(\operatorname{Sit} / A_{i, t-1}\right)+\beta_{3}\left(\Delta \operatorname{Sit} / A_{i, t-1}\right)+\square_{i t}$

where abnormal cash flows is computed as the residual( $\square$ ).

- $C E F$ is the cash flow from operations.

- $A$ is total lagged assets.

- $S$ is sales for the year.

- $\Delta S$ is change in sales from prior to current year.

\section{Abnormal production costs (AB_PROD)}

$\operatorname{PROD}_{i t} A_{i, t-1}=\alpha+\beta_{1}\left(1 / A_{i, t-1}\right)+\beta_{2}\left(S_{i t} A_{i, t-1}\right)+\beta_{3}\left(\Delta S_{i t} A_{i, t-1}\right)+\beta_{4}\left(\Delta S_{i, t-1} / A_{i, t-1}\right)+\square_{i t}$

where abnormal production costs is computed as the residual([?).

- $P R O D$ is cost of sales + the change in inventory from prior to current year.

- $A$ is total lagged assets.

- $S$ is sales for the year.

- $\Delta S$ is change in sales from prior to current year.

\section{Abnormal discretionary expenses (AB_EXP)}

$D I S C \_E X P / A_{i t} A_{i,-1}=\alpha+\beta_{1}\left(1 / A_{i, t-1}\right)+\beta_{2}\left(S_{i, t-1} / A_{i, t-1}\right)+\square_{i t}$

where abnormal discretionary expenses is computed as the residual( $\square$ ).

- DISC_EXP is the sum of research and development and advertising expenditure.

- $A$ is total lagged assets.

- $S$ is sales for the year.

\section{Combined real earnings management (COMBINED_REM)}

COMBINED_REM $M_{i t}=A B_{-} C F O_{i t}-A B_{-} P R O D_{i t}+A B_{-} E X P_{i t}$ 